\title{
Plagiarism of Academic Writing in Malaysian Universities: A legal analysis
}

\author{
Muhamad Ikhwan Mohd Zain1, Nur Ezan Rahmat², Mohd Naqiuddin Zulkarnain³, Shipra Awasthi4 \\ 12 Faculty of Law, Universiti Teknologi MARA, Shah Alam, Malaysia. \\ ${ }^{3}$ Academy of Language Studies, Universiti Teknologi MARA, Pahang, Malaysia. \\ ${ }_{4}^{4}$ Jawaharlal Nehru University, New Delhi, India.
}

ikhwanzaeen@gmail.com, nurezan@uitm.edu.my, mnaqiuddin@uitm.edu.my, shipra2010@gmail.com

Tel: +6014-515 7351

\begin{abstract}
Plagiarism is not a recent issue as it has existed for a long time, especially within the academic world. The study aims to examine the applicable laws in Malaysia relating to plagiarism from the academic's perspective by referring to India as the benchmark jurisdiction. The findings have shown that there are no standard policies for all educational institutions in coping with plagiarism. Therefore, it is recommended that the Malaysian government needs to address the gap in current regulations by having uniform legislation for all institutions on that particular academic misconduct on plagiarism. Keywords: Academic Plagiarism; Research Plagiarism Misconduct; Plagiarism Policy
\end{abstract}

eISSN: 2398-42870 2021. The Authors. Published for AMER ABRA cE-Bs by e-International Publishing House, Ltd., UK. This is an open access article under the CC BYNC-ND license (http://creativecommons.org/licenses/by-nc-nd/4.0/). Peer-review under responsibility of AMER (Association of Malaysian Environment-Behaviour Researchers), ABRA (Association of Behavioural Researchers on Asians/Africans/Arabians) and CE-Bs (Centre for Environment-Behaviour Studies), Faculty of Architecture, Planning \& Surveying, Universiti Teknologi MARA, Malaysia.

DOI: https://doi.org/10.21834/ebpj.v6i16.2709

\subsection{Introduction}

Besides managing classes as their primary responsibility, it is generally known that the academicians in the educational institutions should also conduct research writing. Cheah (2015) stated that Malaysia's higher education needs to achieve the aim of being a regional educational hub. For such intention, academic writing is essential, enhancing the Malaysian community's quality of knowledge. Agonisingly, research misconduct, particularly plagiarism, has tainted academic dishonesty and breach academic integrity. Plagiarism has occurred chiefly among students, and it has been highlighted in many research papers (Singh, 2015; Mustapha et al., 2017; Mohamed et al., 2018; Zejno, 2018). Unexpectedly, academicians have also been reported committing the same misconduct, but those have occurred silently, yet in a more extreme manner. They have not practised the simple 'cut and paste' as what the students have done, yet they have manipulated postgraduate students' work in publishing their articles (Moten, 2014). This study has also acknowledged that there are many reasons for them in doing this undesirable practice. Olesen et al. (2017) have listed several factors and may either be individual, situational, organisational, structural, or cultural. Also, Munigal and Rani (2018) have clearly shown their agreement in stating that plagiarism is a simple way for the authors to reach their goals, rather than spending a long time and effort on their studies or research. Regardless of all the reasons, such dishonesty may destroy academic integrity that every professional is upheld while simultaneously harming the institutions' reputation to improve knowledge sharing quality (Mohamed et al., 2018).

In a particular sense of upgrading the quality of life, academicians should better understand the context of academic integrity. Typically, integrity is the essential value of a person, besides intelligence and energy. In educational institutions, it is solely the integrity

eISSN: 2398-42870 2021. The Authors. Published for AMER ABRA cE-Bs by e-International Publishing House, Ltd., UK. This is an open access article under the CC BYNC-ND license (http://creativecommons.org/licenses/by-nc-nd/4.0/). Peer-review under responsibility of AMER (Association of Malaysian Environment-Behaviour Researchers), ABRA (Association of Behavioural Researchers on Asians/Africans/Arabians) and CE-Bs (Centre for Environment-Behaviour Studies), Faculty of Architecture, Planning \& Surveying, Universiti Teknologi MARA, Malaysia.

DOI: https://doi.org/10.21834/ebpj.v6i16.2709 
of both students and academicians, reflecting their reputation. Singh (2015) has emphasised that academicians are the best person who can educate others on the importance of integrity in the academic system as they are directly indulged in their career's professional and ethical practice. That being said, there are many aspects in which they need to practise integrity, and one of them is through ethical academic research and writing.

In fulfilment of the spirit to strengthen academic writing integrity and uphold justice in the academic world, this paper would like to explore plagiarism's legal jurisdiction distinctly for academicians. The study refers to India as the benchmark country to deal with plagiarism. India is a country in the Asian continent that introduced uniform national legislation for plagiarism including academicians. Towards the end, the study would like to suggest befitting solutions to the Malaysian government to reduce the existing legal framework gap with the specific purpose, upholding academic integrity from the academicians' perspective.

\subsection{Literature Review}

Previous studies have come up with unison that plagiarism is a growing issue in educational institutions. The administration needs to engage with it through relevant and clear policies that prohibit academic plagiarism (Olesen et al., 2017; Mohamed et al., 2018). As persons assumed with high moral and integrity, academicians should be given a specific prohibition clause to show that they are not immune to plagiarism in their research and its legal consequences should they be found doing so.

\subsection{What is plagiarism?}

Plagiarism is one of the academic misconducts within educational institutions. Nevertheless, it is the most dangerous, affecting a professional person's academic integrity and quality. In Malaysia, plagiarism has not yet been considered as either a criminal or civil offence, but rather just one kind of academic misconduct. Lee Harvey (2020) has stressed that plagiarism itself has many definitions, and it differs according to the cultures of the place. A precise explanation is found in Rule 8A under the Educational Institutions (Discipline of Students) Rules 1976, where plagiarism is stated to include taking the idea and claiming it as one's own, which has never contributed to the writing, up to the event of forcing someone to put his name into the research; all these acts are considered plagiarism (Ismail, Pauzi \& Hadi, 2012). Besides, in a decided case of Fauzilah Salleh v Universiti Malaysia Terengganu [2012] 4 CLJ 601, the court has also defined plagiarism as an act of taking a person's idea but with no reference to the real author, which is later claimed as his own (Mohamed et al., 2018). In brief, this study had agreed that plagiarism is defined as when a party took the other's work in bad faith and is later claimed as his contribution or idea, without having any references, citations or even the real author's consent.

\subsection{Plagiarism in Malaysian universities - a real problem}

Though no specific number of cases has been mentioned in any Malaysian websites or public sources, plagiarism has still occurred and is usually settled privately at the university level. Moten (2014) has interviewed the Office of Legal Advisor of an institution in Malaysia and reported that a professor has admitted to committing plagiarism, resulting from his masters and doctoral work students, in producing his articles for publication. Besides that, Olesen et al. (2017) has found out that plagiarism eventually got the highest and most common answer from the interview sessions among the academicians in just one institution. Also, Zejno (2018) has highlighted a plagiarism case by a lecturer who has copied everything from the internet for his teaching materials. This kind of action has proven that plagiarism among academicians is real, but only a few cases are brought to public attention in protecting the institution's goodwill (Olesen et al., 2017). Moreover, Melo (2020) also states that plagiarism has breached the actual author's right and simultaneously has disrespected the research ethics and policies. Therefore, it is crucial to have an explicit prohibition in the regulation to ensure that academics do not simply bypass the system. The authors can take further actions for his rights. To enhance academic integrity, the current law is seen to require a thorough review in balancing rights with responsibilities, even though disciplinary proceedings against staff are the most unpleasant, yet unavoidable, aspect of university governance (Shad Saleem, 2012). By doing so, the academicians' integrity in educational institutions and their quality of life can be boosted.

\subsection{Plagiarism: A Global Concern}

Plagiarism has not only arisen in Malaysia, but it has rapidly expanded all over the world and is bound to be a common problem in the academic world (Singh,2015; Mustapha et al., 2017). Ahmed (2019) has contended that many higher education institutions worldwide, either the developed or developing countries, and from the small elite universities to well-known public ones, have agreed that the problem of plagiarism is continuously increasing among professionals. Furthermore, Matthew (2014) also expects that this is not a simple issue as it involves the professionals, especially the academicians, among the faculty members. Similarly, Wijaya and Gruber (2018) believe that if no systematic rules or laws regulate this matter, the potential of academicians practising plagiarism will upsurge. In India, for example, numerous plagiarism cases have been found in their universities (Chauhan, 2018). That is mainly why they have come up with uniform national legislation for plagiarism in the context of academicians. Palla et al. (2020) has also given their support, stating that such academic misconduct and malpractice keep occurring in the scientific research matter, and plagiarism is proven to be at the third place of common academic misconducts in India.

\subsection{Methodology}

This study adopts the qualitative approach based on doctrinal research using a logically inductive traditional way, and the doctrinal study is dependent on both primary and secondary sources. This study is mainly based on library research and the data collected from primary 
sources, such as statutory laws from both countries Malaysia and India. However, it is also supported with data and information on secondary sources such as journals, articles and internet databases. Following the discussion of the problem statement and the research objectives, the approach describes how to enable the possibility of this study to be done while coming out with the revision and amendment of the current law's provision.

\subsection{Population area}

The study focuses on the data collected from selected Malaysian universities as the source setting. The authors have chosen three universities, i.e. International Islamic University Malaysia (IIUM), Universiti Teknologi MARA (UiTM) and Universiti Sains Malaysia (USM), mainly because they have established their institutional policies or rules precisely on academic plagiarism.

\subsection{Data collection}

Since the study is dealing with academic writing, the most preferred way is library research. Using the keywords 'academic plagiarism', 'research plagiarism misconduct', and 'plagiarism policy', it has found almost 1500 articles on plagiarism from online databases such as Scopus, Emerald and Current Law Journal. By using the advanced keyword of 'academicians', it has been narrowed to 105 literatures. The library research is done consistently to look for the theories, concepts or point of views, and findings to come out with the proposal or amendment in reducing plagiarism cases. Therefore, through the screening and exclusion process, the remaining 18 literatures are bound to contribute significantly to this particular study.

\subsection{Data Analysis}

A detailed analysis and evaluation is employed in comparing the Malaysian legislation with the Indian legislation, particularly on academic plagiarism; the findings may either support or contradict the study's objectives on the legal issues of academic plagiarism. Such a detailed analysis and evaluation have helped address the problem and give a clearer picture to appropriately support the research questions and research objectives. Hence, the study has drawn a comparison between the two chosen legislations in proving the relevant improvement that can be adopted.

\subsection{Findings}

\subsection{Relevant legal provision in the educational institution}

Under the Malaysian Ministry of Higher Education, the study has analysed several legislations concerning educational institutions. Mohamed et al. (2018) has stated that the Universities \& University Colleges Act 1971 (Act 30) is the leading Act which governed all aspects of establishing, maintaining, and administering universities and university colleges in Malaysia. Moreover, the Private Higher Learning Educational Institutions Act 1996 (Act 555) is also found to be another significant Act that expressly provides for the establishment, registration, management, and supervision of controlling the private higher educational institutions' quality of education. The disciplinary actions are mentioned in section 46 and are read together with section 49, but those have only focused on the students' perspective; the staff's disciplinary action has not been mentioned at all. Besides, the Educational Institution (Discipline) Act 1976 (Act 174) has also described the disciplinary offences in the educational institution. Interestingly, there is a prohibition of plagiarism under rule $8 \mathrm{~A}$ which gives the precise definition and types of plagiarism (Ismail, Pauzi \& Hadi, 2012), when being read together with UiTM Plagiarism policy.

In line with that, other general provisions applied to the government officers may also be discussed-mainly, the Statutory Bodies (Discipline and Surcharge) Act 2000 (Act 605). Wan and Chang (2019) have contended that since Act 30 has no power over the academicians, this Act may cover the officer's disciplinary offence in general. The study also believes that academic plagiarism is a seriously wrongful act which cannot be treated in a general way, but there must be a precisely mentioned prohibition on it. The National Council on Higher Education Act 1996 (Act 546), which is enacted merely to establish the National Council on higher education and provide for its functions relating to higher education and matters connected (Mohamed et al., 2018), though significantly important, have had no say on academic plagiarism.

As plagiarism can affect the academicians' academic integrity, some institutions have initiated their policies and rules on academic plagiarism. For example, the IIUM Staff Disciplinary Rules 2015 have clearly expressed that an IIUM staff member shall not plagiarise another person's intellectual property under section 19(1) of the rule. Similarly, the Universiti Sains Malaysia Policy on Plagiarism has also highlighted the institution's importance of academic integrity, applicable to students and staff. It is magnificent for those institutions to produce the policies, yet it is literally the inconsistencies between the institutions that have created confusion and uncertainty in understanding the prohibition of plagiarism (Eric \& Gokmenoglu, 2010). The summary of the aforementioned legislations can be seen as follows:

Table 1: The Plagiarism prohibition in Malaysian Legal Framework

\begin{tabular}{lll}
\hline The Malaysian Education Law & Students & Academician \\
\hline Educational Institution (Discipline) Act 1976 \& UiTM & Rule 8A & Not applicable \\
Plagiarism policy & & \\
IIUM Staff Disciplinary Rules 2015 & Not applicable & Section 19(1) \\
Universiti Sains Malaysia Policy on Plagiarism & Para 2.1 \& 2.4 & Para 2.1 \& 2.4 \\
\hline \multicolumn{2}{c}{ Source: ( Ismail, Pauzi \& Hadi, 2012; Mohamed et al., 2018) }
\end{tabular}


The table has concisely shown that there is no proper parent law that prohibits plagiarism as misconduct among academicians. Thus, this study suggests that every institution in Malaysia is appropriating a national standard of plagiarism law. It is recommended that the Indian provision is referred to as the benchmark to improve the current inconsistent law, as they already have a centralised regulation to curb academic plagiarism at the national level. Singh and Pandita (2019) have asserted that as the researchers in India are hastily practising plagiarism, the University Grants Commission (UGC), as the highest controlling body for higher education under the government in India, has adopted a standard regulation to promote academic integrity and prevent plagiarism in all higher educational institutions (Gupta, 2016; Ingle, 2019). Besides having several anti-plagiarism software such as 'iThenticate' and 'Turnitin' (Singh, 2016), they have introduced a standard regulation known as UGC Regulation 2018; all Indian institutions can refer to only one formal regulation (Kadam, 2018). Furthermore, Awasthi (2019) has also acknowledged the properly classified anti-plagiarism software in checking the similarity in writing. Under the regulation, plagiarism is classified into four different levels: beginning from the not penalised 10 percent of similarity in the writing, up to 60 percent in constituting the highest plagiarism level, different penalties are amounted accordingly. With the help of the Plagiarism Disciplinary Authority (PDA) and the Academic Misconduct Panels (AMP), UGC believes that it can achieve the zero-tolerance policy in core research areas (Malhotra, 2019; Arun, 2019; Awasthi, 2019). UGC has also published a document entitled Good Academic Research Practices for the research community to follow ethics and maintain academic integrity. Further, the document states the procedures and other measures that the researchers need to follow at different levels while pursuing their research (UGC Good Academic Research Practices, 2020). In support of that, UGC has approved two-credit courses, "Research and Publication Ethics", to create awareness about publication ethics and academic misconduct. The course is compulsory for PhD scholars to undertake (UGC, Research and Publication Ethics, 2019).

Be that as it may, even with the aid of softwares in detecting academic plagiarism in research, the strict implementation of the policies is needed to punish those involved in any stated category of plagiarism properly. It may deter the academicians from repeating the action. The table below summarises the comparison between the legal framework on academic plagiarism in Malaysia and India:

Table 2: The Comparison of Legal Framework

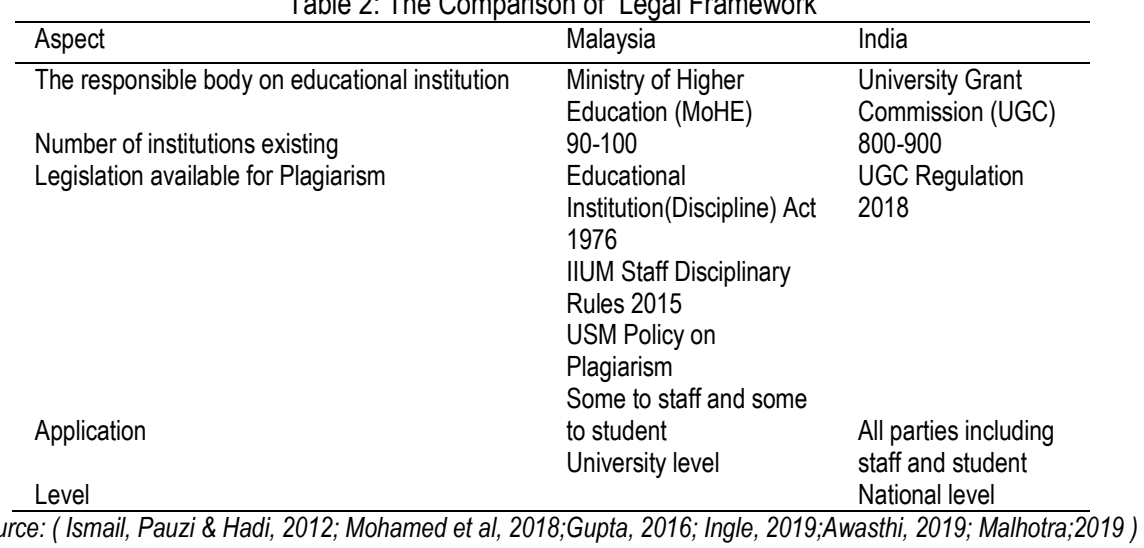

\subsection{The loophole in the Malaysian legal framework}

The study has identified that the Educational Institution (Discipline) Act 1976 is not comprehensive enough to deal with academic plagiarism. Even though it has existed for quite some period, Rule $8 \mathrm{~A}$ of the Act is only focused on the students' perspective. It has nothing to do with the academicians' as if the academicians can efficiently plagiarise with no prohibition. It is a serious matter, as academic plagiarism, which is done by academicians should be considered seriously abusive in the field of knowledge. Academics is a professional person involved in a professional career should always observe the integrity in carrying out the responsibility. Moreover, the Act does not generally apply to all universities except for UiTM, as it is enacted explicitly for all polytechnics and colleges. In ensuring that it is effective and can be imposed on all institutions and parties involved, this kind of loophole must be catered comprehensively. Although the educational institution has so many existing legal frameworks, the clear and fixed written plagiarism and ethics policies are insisted on catering to the profession's harmful problem (Awasthi, 2019). It is suggested by Ahmed (2019) that the government in the Middle East and Asia to be having a strict rule and regulation imposed on all communities, and Malaysia herself shall take part in it to prove that academicians should not be privileged in this crucial matter. Apparently, all parties need to be treated equally and thoroughly in creating an academic integrity culture with positive life qualities in all educational institutions.

Moreover, since there is no proper law enacted to deal with plagiarism, it is merely considered as an ethical issue rather than legal issues. The case is mostly settled at the institution level, and no legal action is brought before the Malaysian court. Therefore, no academic plagiarism cases in legal laws are recorded, except when the parties involved are being sued on defamation or any other legal basis.

\subsection{Discussion}

Plagiarism can harm the institution, and therefore serious attention shall be given. There is a need for the government to put an extra effort to amend the existing law to provide a superior regulation for educational institutions. Instantaneously, the level of academic integrity and the quality of life among educators and within the educational institutions' compound can be intensified. The study has 
taken into consideration that Nurul, Hasnah and Ishak (2019) has categorised many examples of misconducts among academicians, such as being biased in grading, abuse of authority, or having a relationship with the student. Yet, the most dangerous and unacceptable misconduct would be research plagiarism. As for the time being, Vasilleva and Chankova (2019) have stated that they do not deny the detection softwares' help in controlling plagiarism. However, it cannot be considered the sole solution but only to support the legal provision as the study believes it is vital to have prevention rather than detection. The fact that the number of educational institutions keeps increasing year after year has simultaneously increased the number of research publications (Malhotra, 2019). While plagiarism in Malaysia mostly happens in secret, less attention is paid as if no such situations have occurred. However, in other countries, many research studies have been done regarding the particular issue.

Debnath and Cariappa (2018) have shown agreement to have an exact policy on plagiarism for all academic papers with explicit instruction available online to the authors in preventing plagiarism. Therefore, a good initiative is taken by the Indian government to enforce a clear plagiarism law to the academics in all institutions, namely UGC Regulation 2018 (Singh, 2016). All the academicians, researchers, and policy-makers have agreed with the implementation as they know that the law could strictly control plagiarism (Chauhan, 2018). Since India shows that it is possible to have a standard rule with that same enthusiasm, Malaysia should instead produce its customary law and intensely combat plagiarism.

\subsection{Implication}

The researchers focused on the solution-based through the enactment of relevant legislation to the educational institution. The study believed that curbing plagiarism through law enforcement may uphold academic integrity and treat the public's right fairly and squarely

\subsection{Limitation of the Study}

Little study has been done in addressing plagiarism within academicians from the legal viewpoint. Most papers are discussed from a different perspective, such as the reasons and factors, the challenges and anti-plagiarism software strategies. Also, the problem is settled on a personal level, and thus no exact statistics of cases can support the prevalence of the study.

\subsection{Conclusion and Recommendations}

As a massive problem in the academic world, plagiarism needs serious attention from the stakeholder. It is undeniable there are so many legal frameworks in making sure the educational institution functions well. Yet, the prohibition towards plagiarism is in question though it is a severe problem since numerous years ago. It cannot be treated as academic culture in the educational institution; even it had to be a norm before. It's time to make a change. The government shall be the game-changer in preserving the quality of knowledge. The institution shall prepare at its best in avoiding plagiarism to avoid any threat to the institution's performance and quality of life, in line with the Malaysian Higher Education Strategic Plan to produce a first-class human intellect.

Therefore, the Malaysian government and universities must take fast action to upgrade the legislative approach, focusing on combating plagiarism to both staff and students. The Ministry of Higher Education (MoHE) may review the law by upgrading the existing parent Act or combining several existing policies and rules in universities to produce a comprehensive law on every institution to coordinate plagiarism and create a uniform standard law in all institutions. Such policy should also be made known to all academics (Nurul, Hasnah \& Ishak, 2019), which can ultimately help decrease the irregularities of understanding the national education legislation's concept.

Future studies should conduct some in-depth interview sessions with academics in Malaysian universities to look into their perspectives on plagiarism's legal application.

\section{Acknowledgement}

The authors would like to acknowledge all support from the Institute of Graduate Studies (IGS) and Faculty of Law, Universiti Teknologi MARA (UiTM) Shah Alam for providing financial research funds, and all respected parties for the helpful opinions and recommendations.

\section{Paper Contribution to Related Field of Study}

All higher education institutions in Malaysia can refer to a standard and published regulation involving academic misconduct that provides clear policy and rules imposed on academics. This research is expected to explore something fresh that will benefit the academicians and the entire educational system.

\section{References}

Ahmed, K. (2020). Academic integrity: Challenges and strategies for Asia and the Middle East. Accountability in research, 27(5), 256-270.

Awasthi, S. (2019). Plagiarism and Academic Misconduct: A Systematic Review. DESIDOC Journal of Library \& Information Technology, 39(2).

Chauhan, S. K. (2018). Research on Plagiarism in India during 2002-2016: A Bibliometric Analysis. DESIDOC Journal of Library \& Information Technology, 38(2). 
Cheah J.K.S. (2016) Perspectives on Academic Plagiarism in Malaysia. In: Bretag T. (eds) Handbook of Academic Integrity. Springer, Singapore https://doi.org/10.1007/978-981-287-098-8_5

Debnath, J., \& Cariappa, M. P. (2018). Wishing away Plagiarism in Scientific Publications! Will it work? A situational analysis of Plagiarism policy of journals in PubMed. Medical Journal Armed Forces India, 74(2), 143-147.

Education Malaysia Global Services. (n.d.) Retrieved 28 January 2021, from https://educationmalaysia.gov.my/malaysia-higher-education-in-brief/

Gupta, V. (2016). Deterring Plagiarism, The Need Of The Hour: A Comparative Study Of Steps Taken In Higher Education System In India And The United States. International Journal of Advanced Research, 4(10), 793-796. https://doi.org/10.21474//JAR01/1859

Ishak, N. K., Haron, H., \& Ismail, I. (2019). Ethical Leadership, Ethical Climate and Unethical Behaviour in Institutions of Higher Learning. KnE Social Sciences, 408422. DOI 10.18502/kss.v3i22.5064

Ismail, I. R., Pauzi, S. F. M., \& Abd Hadi, K. A. (2012). Students Plagiarism and Copyright Infringement: A Malaysian Legal Perspective.

Kadam, D. (2018). Academic integrity and plagiarism: The new regulations in India. Indian journal of plastic surgery: official publication of the Association of Plastic Surgeons of India, 51(2), 109.

Malhotra, S. (2019). Research Impediments and Challenges in Indian Academia: Conquering them Ethically. International Journal of Advanced Science and Technology, 28 (16), 514-520

Melo, L., Soto-Ardila, L. M., Luengo, R., \& Carvalho, J. L. (2019, October). Ideas About Plagiarism and Self-plagiarism with University Professors and Researchers: A Case Study with WebQDA. In World Conference on Qualitative Research (pp. 206-215). Springer, Cham.

Mohamed, K., Abdul Samat, N. H., Abd Aziz, A. S., Mohd Noor, N. A., \& Ismail, N. (2018). Academic plagiarism in Malaysia higher education institutions: a legal perspective. International Journal of Law, Government and Communication, 3(13), 245-253.

Moten, A. R. (2014). Academic dishonesty and misconduct: Curbing plagiarism in the Muslim world. Intellectual Discourse, 22(2).

Munigal, A., \& Rani, B. R. (2018). Socio-Legal Perspective on Academic, Research and Scientific Misconduct in India. In 2018 5th International Symposium on Emerging Trends and Technologies in Libraries and Information Services (ETTLIS) (pp. 319-321). IEEE.

Mustapha, R., Hussin, Z., Siraj, S., \& Darusalam, G. (2017). Academic dishonesty among higher education students: The Malaysian evidence (2014 To 2016). KATHAThe Official Journal of the Centre for Civilisational Dialogue, 13(1), 73-93

Olesen, A. P., Amin, L., \& Mahadi, Z. (2018). In their own words: research misconduct from the perspective of researchers in Malaysian universities. Science and engineering ethics, 24(6), 1755-1776.

Palla, I. A., Singson, M., \& Thiyagarajan, S. (2020). A comparative analysis of retracted papers in Health Sciences from China and India. Accountability in research, 27(7), 401-416.

Shad Saleem Faruqi. (2012). Regulating staff discipline. Retrieved 19 January 2021 from https://www.thestar.com.my/opinion/columnists/reflecting-on-thelaw/2012/01/25/regulating-staff-discipline

Singh, B. P. (2016). Preventing plagiarism in a digital age with special reference to Indian Universities. International Journal of Information Dissemination and Technology, 6(4), 281-287

Singh, M. K. M. (2015). Malaysian Public University Students 'attitude Towards Plagiarism. Language \& Communication, 2(2), $133-145$.

UGC Good Academic Research Practices (2020). Retrieved 20 January 2021 from https://www.ugc.ac.in/ebook/UGC_GARP_2020_Good\%20Academic\%20Research\%20Practices.pdf

University Grants Commission (Promotion of Academic Integrity and Prevention of Plagiarism in Higher Educational Institutions). (2018). Retrieved 2 January 2021 from https://www.ugc.ac.in/pdfnews/7771545_academic-integrity-Regulation2018.pdf

Wijaya, H., \& Gruber, K. E. (2018). Ethics perspective and regulation of plagiarism in Higher Education. International Journal of Humanities and Innovation (IJHI), 1(1), $17-25$

Williams, A. S. (2020). Unaligned or Unified: A Content Analysis of New Jersey's Public Higher-Education Institutions' Policies on Plagiarism (Doctoral dissertation, Wilmington University (Delaware)).

Zejno, B. (2018). Plagiarism in Academic Writing among Students of Higher Learning Institutions in Malaysia: An Islamic Perspective. Journal of Education and Social Sciences, 9(3), 1-14. 